\title{
Prosperity of community pharmacy evaluated by gross and net profit and suggested corrective measures. 10 years study Prosperita verejnej lekárne hodnotená prostredníctvom hrubého a čistého zisku a opatrenia vedúce $k$ ich náprave. 10 ročná štúdia
}

\author{
Malovecká, I. ${ }^{\circledR}$, Papargyris, K. ${ }^{1}$, Mináriková, D. ${ }^{1}$, Foltán V. ${ }^{1}$, Jankovská, A. ${ }^{2}$ \\ ${ }^{1}$ Comenius University in Bratislava, Faculty of Pharmacy, \\ Department of Organisation and Management in \\ Pharmacy, Bratislava, Slovak Republic \\ ${ }^{2}$ University of Economics in Bratislava \\ Faculty of National Economy, Department of Finance, \\ Banking and Investment, Bratislava Slovak Republic \\ 'Univerzita Komenského v Bratislave, Farmaceutická fakulta, \\ Katedra organizácie a riadenia farmácie, Bratislava, \\ Slovenská republika \\ ${ }^{2}$ Ekonomická Univerzita v Bratislave, Národohospodárska \\ Fakulta, Katedra financií, bankovníctva a investovania, \\ Bratislava, Slovenská republika
}

Received January 2, 2015, accepted April 4, 2015

Abstract Monitoring, calculation and assessment of community pharmacy prosperity with the help of financial analysis indicators for years 2003-2012, using financial statements was conducted, with respect to profitability parameters such as gross and net profit ratios. These ratios reflect various changes that hold between years 2003 and 2012 . Under the time of financial crisis, recession and serious socioeconomic changes the profitability parameter gross profit ranged from $x_{2003}-2011=14.3-22.8 \%(a v e r a g e=19.2 \%$, mean $=19.8 \%, \boldsymbol{\sigma}=2.4)$, but in 2012 decreased on $14.3 \%$. Net profit ranged $x_{2003-2011=} 2.3-18.3 \%($ average $=14.6 \%$, mean $=16.6 \%, \boldsymbol{\sigma}$ $=4.9$ ), while in 2012 reached only $2.3 \%$. All changes that have taken place in the society had impact on community pharmacy finance by worsening its profitability. Therefore, the stability of community pharmacy may be threatened and may affect its future performance.

Slovak Monitorovanie, výpočet a hodnotenie prosperity verejnej lekárne pomocou metódy finančnej analýzy z účtovných dokladov abstract bolo uskutočnené za roky 2003 - 2012. Počítané boli ukazovatele ziskovosti, ako hrubý a čistý zisk. Ukazovatele odrážajú mnohé zmeny, ktoré nastali v rokoch 2003 až 2012. V dôsledku finančnej krízy, recesie a vážnych socioekonomických zmien sa ukazovatel' hrubého zisku pohyboval v rozpätí $x_{2003-2011}=14,3-22,8 \%$ (priemer $=19,2 \%$, median $\left.=19,8 \%, \sigma=2,4\right)$, ale v roku 2012 klesol na $14,3 \%$. Ukazovatel' čistého zisku sa pohyboval v rozpätí x $x_{2003-2011}=0-18,3 \%$ (priemer $=14,6 \%$, median = 16,6 \%, $\sigma=4,9$ ), zatial' čo v roku 2012 dosiahol len 2,3\%. Zmeny ktoré prebehli v spoločnosti mali dopad na ekonomiku verejnej lekárne. Prejavili sa zhoršením jej ziskovosti, a tým ohrozením stability verejnej lekárne do budúcnosti.

Keywords community pharmacy-prosperity-financial analysis-gross profit-net profit-corrective measures-financial crisis

Klúčové verejná lekáreň - prosperita - fianačná analýza - hrubýzisk - čistý zisk - nápravné opatrenia - finančná kríza

slová:

\section{INTRODUCTION}

Community pharmacies nowadays play a crucial role in the health status of a society. They are health care units designed to provide pharmaceutical care. They constitute the direct providers of medicines and the basic contributors in the provision of pharmaceutical services to patients (Cheng et al., 2013). Once financial crisis started to spread worldwide, it was anticipated the affection of more and more countries by this global phenomenon and the expansion of a negative impact on their economic growth and development (Ifanti et al.,
2013). Financial crisis, characterised by general economic slowdown, reduced retail growth and decreased profit margins, has placed the health care system into a very difficult position (Gorantis et al., 2014). Also the employees feel the impact of the recent economic crisis on employee workrelated attitudes via changes in regulatory focus (Markovits et al., 2014).

At the present time, community pharmacy is going through very tough moments, since it daily faces financial constraints 
and economic pressure (Vogler et al., 2014). Furthermore, health care market has been deregulated in such a way that revenues are diminished for the new participants entering the market. All these effects of financial crisis are creating a considerable financial pressure on community pharmacy which is also daily confronted with accelerated competition (Jacobs et al., 2013). In order to alleviate the problems, generated mainly by financial crisis, the role of the pharmacist is gradually and progressively changing (Bush et al., 2009; McMillan et al., 2013). Despite the difficult time that it faces, community pharmacy must maintain its operation and survive at the upcoming time (Norris et al., 2014).

Except for social and medical objectives, there is also the economic objective of a community pharmacy that is focused on generating profit. Gaining profit is of great importance not only for the existence of the community pharmacy but also for its further development (Keast et al., 2010, Perepelkin and Dobson, 2010). Gaining profit can be limited by the provision of pharmaceutical care to concrete patients (Carroll et al., 1996). In order to assure its financial stability, a community pharmacy should possess and manage sufficient funds so as to cover its obligations and to normally run the business. During the normal operation of a community pharmacy, in the provision of pharmaceutical care, inputs form the bulk of the costs and outputs the revenues. The difference between costs and revenues is the profit of the community pharmacy. Operating order of the community pharmacy is required so as to ensure its proper operation (Herist et al., 2011). The necessary parts that contribute to this proper operation include the existence and careful management of organisational structure of the pharmacy, pharmacy premises, pharmacy stuff and their premises as well as loyal following of a hygienic and sanitation program.

\section{AIMS AND OBJECTIVES}

The principal objective of the work is to assess the financial performance of pharmacy services provided by an independent community pharmacy. Article focuses on total revenue and costs of the community pharmacy's overall operations. Ten years (2003-2012) of pharmacy records are examined in order to evaluate the profitability characteristics such as gross and net profit ratios. These ratios constitute significant parameters in providing useful information concerning the financial health of the independent community pharmacy. The better the understanding of the profitability ratios, the greater will be the improvement in managing and controlling the services and finances of the independent community pharmacy.

\section{METHODOLOGY AND RESEARCH METHODS}

The methodology conducted relies on the calculation, monitoring and assessment of financial indicators which are critical for the financial analysis of the independent community pharmacy business. The evaluation of profitability indicators is based on the analysis of the figures reported on the financial statements of the enterprise. They are profit and loss statement and balance sheet. Examined data were collected for the period 2003-2012. After acquisition, financial data were converted into ratios to provide a complete view of the community pharmacy's business, adjustments for inflation to overcome the shortfalls that may occur in a longer decade analysis. The calculation for Gross profit margin ratio $(\%)=$ (gross profit $\div$ income $) \times 100$ and for Net profit margin ratio $(\%)=($ net profit $\div$ income $) \times 100$.

\section{RESULTS AND DISCUSSION}

The analyzed profitability ratios of the community pharmacy during the given decade had the course shown in the graphic illustration 1.

To observe from the graphic illustration, gross profit margin ratio fell in 2004 and since 2005 has remained relatively flat up to 2009. In 2010, there has been an inclining trend to the ratio but afterward the gross margins have recorded a significant downward trend. This declining trend was culminated in 2012 , the year that has been recorded the lowest value of the

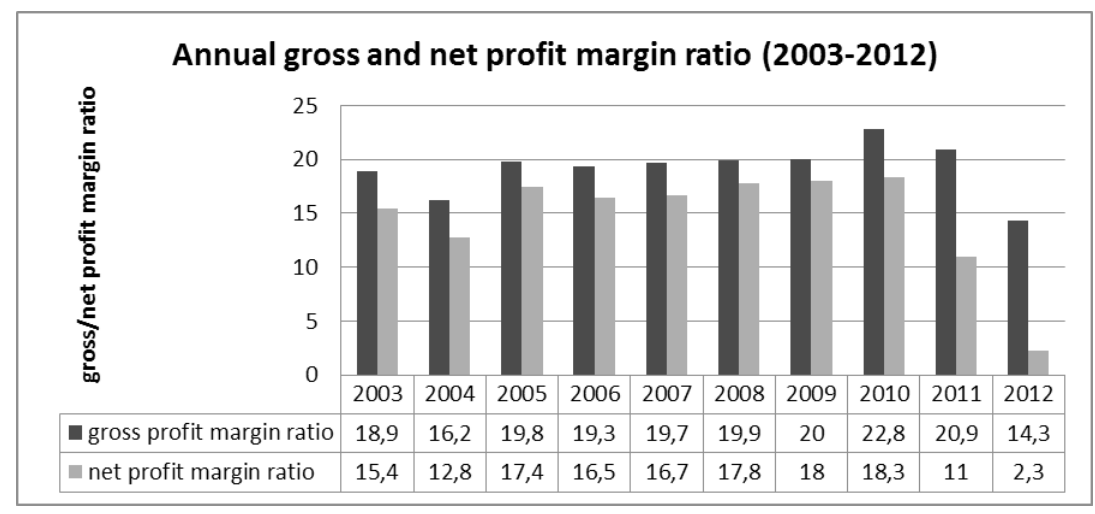

Figure 1. Annual profitability ratios (gross and net profit margin ratios) of the community pharmacy for the years 2003-2012 
gross profit margin ratio $(14.3$, average $=19.2 \%$, mean $=19.8 \%$, $\boldsymbol{\sigma}=2.4$ ) in comparison with the whole examined decade. This declining trend signifies that community pharmacy generates a low level of revenue to pay for its operating expenses and net profit. Also it indicates that the enterprise is not keeping production and inventory costs under control. Moreover, it may also mean that prices have been set too low. In order to inhibit this downward trend of the ratio, the examined community pharmacy should promptly proceed to the implementation of some necessary corrective actions. Such actions include suggestions towards the improvement of the business's operations. Community pharmacy in order to remain financially viable should decrease the cost of goods sold and generally develop a better managing and control of cost of goods sold (COGS). Also it should manage and revise pricing either by setting prices higher or even by decreasing possible cash discounts. Obviously, higher gross profit is more advantageous than lower one, since making a profit is the primary business objective. Higher sales prices and lower inventory purchase prices are both contributing to maximise gross profit. Therefore, by performing such improvements, examined community pharmacy will find it less difficult to maintain acceptable gross margins to pay the personnel and operating costs of the business's managing.

The net profit margin ratio in the observed decade fell in 2004 as well as gross profit margin and since 2005 has remained relatively flat up to 2010 . In 2011, it has been recorded a significant downward trend to the ratio. This declining trend was culminated in 2012, year that it has been recorded the lowest value of net profit margin ratio $(2.3$, average $=14.6 \%$, mean $=16.6 \%, \sigma=4.9$ ) in comparison with the values achieved during the whole examined decade. The last accelerated declining tendency of the ratio reflects an alarming condition for the independent community pharmacy. It primarily shows that community pharmacy is not generating enough sales and additionally that its gross profit margin is relatively low. Furthermore, it denotes that the business is unable to keep operating expenses under control so as to leave an acceptable profit. Also, such a decrease in the ratio as reported on 2012 may signify a business's susceptibility to cost blowouts. The final value of the ratio reflects that community pharmacy is almost generating no profit for its operations, condition that might indicate the need to take on debt to pay its expenses. In order to survive from this alarming downtrend of the net profit margin ratio, examined community pharmacy should mandatorily and directly proceed to the implementation of certain appropriate corrective actions. Such actions should be instantly performed, since at this moment, community pharmacy has been financially placed one step before taking on debt. The most prominent action that community pharmacy's business should take in order to remain financially viable is to try and reduce fixed and variable costs. Decreasing payroll expenses should be an essential and vital remedial effort. Payroll expenses include all wages and salaries, employee taxes and generally all benefits for all staff of the business including owners (Malovecka et al, 2013). Moreover, community pharmacy should also decrease all other operating expenses, frequently referred to as overhead. These expenses include advertising, insurance, store supplies, containers and labels, delivery expenses, office postage, computer expenses, rent, utilities and telephone. Additionally, it should decrease COGS and revise pricing so as to achieve higher gross profit margins. Except for lowering its payroll expenses and controlling other operating expenses, community pharmacy should proceed to certain efficiency improvements such as increasing the use of technology through investing in laborsaving technologies. Besides, enterprise should look over obtaining revenue for medication therapy management services provided (Smith et al., 2014). By performing such corrective actions, business's net profit margin ratio annual values will slowly but surely conduct an increasing trend. As a result, examined community pharmacy will strengthen its financial position over time and progressively start to generate an acceptable profit in the near future.

Many external and internal factors affect the public pharmacy performance. The number of patients-customers visited the pharmacy can be marked as a crucial factor (Radford et al. 2009) that affects income and turnover of the enterprise. This factor is not included in methods of financial analysis. Therefore we considered it necessary to evaluate. As it is not a part of financial analysis we have to assess it separately. The statistical information of the examined decade was obtained from the accounting office of the enterprise after taking into account all sales and receipts of the business for every single year. Table 1 provides an overview of the annual amount of customers who visited the pharmacy and the approximate average amount of patients who visited the pharmacy each single day of every examined fiscal year.

On 2005 was recorded an increasing trend to the number of customers who visited the pharmacy. From 2005 up to 2008, the amount of customers who visited the pharmacy remained relatively flat. However, from 2009 up to 2012, it has been observed an accelerated declining trend to the annual and daily amount of patients who visited the pharmacy. This condition obviously reflects the deep impact of the financial crisis to the pharmacy practice. The dramatically decreased number of customers during the last four years explains the problematic ability of the business to generate profit. The accelerated changes in the financial and economic profile of the country led people to minimise their visits to the pharmacy and become more conservative in their expenses for pharmaceutical goods or services (Sánchez-Serrano, 2011).

During the period of recession, serious socioeconomic changes occurred. Salaries of employees, pensions and other benefits that were handed out in reasonable levels before the crisis have been reduced dramatically (Matsaganis, 2013). This condition resulted in a noticeable decrease in the ability of consumers to purchase products intended both for health and cosmetic aspects (Soderberg, 2012). In specific, 
Table 1. Number of customers who visited the community pharmacy

\begin{tabular}{|c|c|c|c|c|c|c|c|c|c|c|c|c|c|c|}
\hline & \multicolumn{9}{|c|}{ Fiscal year } & & & & & \\
\hline $\begin{array}{c}\text { Customers } \\
\text { visited the } \\
\text { community } \\
\text { pharmacy }\end{array}$ & 2003 & 2004 & 2005 & 2006 & 2007 & 2008 & 2009 & 2010 & 2011 & 2012 & average & mean & min & max \\
\hline $\begin{array}{c}\text { Number of } \\
\text { customers } \\
\text { per year }\end{array}$ & 27240 & 25548 & 31284 & 29492 & 29500 & 29885 & 23305 & 20810 & 18619 & 15099 & 25078 & 26394 & 15099 & 29885 \\
\hline $\begin{array}{c}\text { Average } \\
\text { number of } \\
\text { customers } \\
\text { per working } \\
\text { day }\end{array}$ & 101 & 95 & 116 & 109 & 109 & 111 & 86 & 77 & 69 & 56 & 93 & 98 & 56 & 111 \\
\hline
\end{tabular}

it has been observed a significant change in the habits and behavior of consumers, guiding them to decrease their spontaneous purchases, postponing possible purchases and generally decrease their total purchases (Belvis et al., 2012). Furthermore, the priorities of customers in buying products have been switched over, to either choosing the cheapest form or not buying anything at all, even at the cost of their own health (Ásgeirsdóttir et al., 2014). This situation caused a serious decrease in the income of the pharmacy and posed limitations on the ability of pharmacists to ensure financial stability for their businesses.

\section{CONCLUSION}

Evaluation of community pharmacy operations and overall performing is essential at the time of financial crisis, recession and serious socioeconomic changes. Using the method of financial analysis and valuating gross and net profit ratios can bring the owner or manager of community pharmacy a lot of benefits towards prosperity and future development of the community pharmacy. Analysis not only tells about the performance of the community pharmacy's business but also helps to determine its overall financial health and tells what might be the future.

\section{References}

[1] Cheng Y, Raisch DW, Borrego ME, Gupchup GV. Research in Social and Administrative Pharmacy, 9(3), 2013, 311-329.

[2] Ifanti AA, Argyriou AA, Kalofonou FH, Kalofonos HP. Financial crisis and austerity measures in Greece: Their impact on health promotion policies and public health care. Health Policy, 113 (1-2), 2013, 8-12.

[3] Goranitis I, Siskou O, Liaropoulos L. Health policy making under information constraints: An evaluation of the policy responses to the economic crisis in Greece. Health Policy, Accepted Manuscript, Available online 1 August 2014

[4] Markovits Y, Boer D, van Dick R. Economic crisis and the employee: The effects of economic crisis on employee job satisfaction, commitment, and self-regulation. European Management

\section{ACKNOWLEDGMENT}

This contribution/publication is the result of the project implementation: Comenius University in Bratislava Science Park supported by the Research and Development Operational Programme funded by the ERDF

Grant number: ITMS 26240220086.

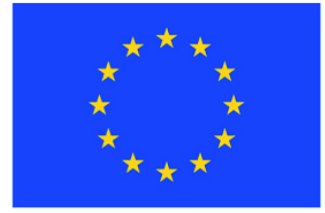

Európska únia

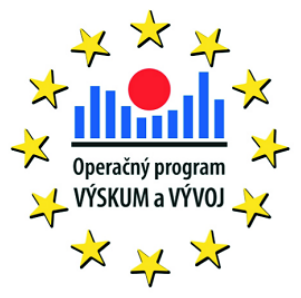

Podporujeme výskumné aktivity na Slovensku/Projekt je spolufinancovaný zo zdrojov EÚ

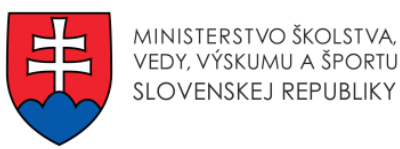

Journal, 32 (3), 2014, 413-422.

[5] Jacobs S, Schafheutle El, Jee SD, Elvey R, Hassell H, Noyce PR. Existing arrangements for monitoring community pharmacies in England: Can they have a role in the revalidation of pharmacists? Research in Social and Administrative Pharmacy, 9(2), 2013, 166177.

[6] Bush J, Langley CA, Wilson KA. The corporatization of community pharmacy: Implications for service provision, the public health function, and pharmacy's claims to professional status in the United Kingdom. Research in Social and Administrative Pharmacy, 5(4), 2009, 305-318.

[7] McMillan SS, Wheeler AJ, Sav A, King MA, Whitty JA, Kendall E, Kell F. Community pharmacy in Australia: $A$ health hub destination of 


\section{Prosperity of community pharmacy evaluated by gross and net profit and suggested...}

the future. Research in Social and Administrative Pharmacy, 9(6), 2013, 863-875.

[8] Keast SL, Jacobs E, Harrison D, Farmer K, Thompson D. Future economic outlook of Nebraska rural community pharmacies based on break-even analysis of community operational costs and county population. Research in Social and Administrative Pharmacy, 6(3), 2010, 209-220.

[9] Norris P, Horsburgh S, Sides G, Ram, Fraser J. Geographical access to community pharmacies in New Zealand. Health \& Place, 29(1), 2014, 140-145.

[10] Perepelkin J, Dobson RT. Influence of ownership type on role orientation, role affinity, and role conflict among community pharmacy managers and owners in Canada. Research in Social and Administrative Pharmacy, 6(4), 2010, 280-292.

[11] Carroll NC, Miederhoff PA, Waters LW. Profitability, third-party reimbursement, and access to community pharmacies. Clinical Therapeutics, 8(4), 1996, 703-715.

[12] Herist N, Rollins B, Perri M. Financial Analysis in Pharmacy Practice. London: Pharmaceutical Press; 2011.

[13] Burke S, Thomas S, Barry S, Keegan C. Indicators of health system coverage and activity in Ireland during the economic crisis 20082014 - From 'more with less' to 'less with less'. Health Policy, In Press, Corrected Proof, Available online 17 July 2014

[14] Vogler S, Habimana K, Art D. Does deregulation in community pharmacy impact accessibility of medicines, quality of pharmacy services and costs? Evidence from nine European countries. Health Policy, In Press, Corrected Proof, Available online 8 June 2014.

[15] Matsaganis M, The Greek Crisis: Social Impact and Policy Responses, Department of Western Europe/North America, Berlin, 2013.
[16] de Belvis AG, Ferrè F, Specchia MC, Valerio L, Fattore G, Ricciardi W. The financial crisis in Italy: Implications for the healthcare sector. Health Policy, 106(1), 2012, 10-16.

[17] Ásgeirsdóttir TL, Corman H, Noonan K, Ólafsdóttir P, Reichman NE. Was the economic crisis of 2008 good for Icelanders? Impact on health behaviors. Economics \& Human Biology, 13(1), 2014, 1-19.

[18] Sánchez-Serrano I. The World's Health Care Crisis: The United States' Leadership. The World's Health Care Crisis, 2011, 3-28.

[19] Söderberg IL, Wester M. Lay actions in the face of crisis-Swedish citizens' actions in response to the global financial crisis of 2008. The Journal of Socio-Economics, 41(6), 2012, 796-805.

[20] Malovecká I, Mináriková D, Lehocká L', Foltán V. New types of assessments of community pharmacy technology business and ther contribution towards prosperity of the community pharmacy. Acta Facultatis Pharmaceuticae Universitatis Comenianae. 2013, 60(1), 35-42.

[21] Smith M, Cannon-Breland ML, Spiggle S. Consumer, physician, and payer perspectives on primary care medication management services with a shared resource pharmacists network. Research in Social and Administrative Pharmacy, 10 (3), 2014, 539-553.

[22] Radford A, Mason M, Richardson I, Rutledge S, Poley S, Mueller K, Slifkin R. Continuing effects of Medicare Part D on rural independent pharmacies who are the sole retail provider in their community. Research in Social and Administrative Pharmacy, 5(1), 2009, 17-30. 